\title{
Development of Electronic Good Governance Based Investment License System in the City of Semarang
}

\author{
Henny Juliani ${ }^{1}$, Kadek Cahya Susila Wibawa ${ }^{2}$ \\ \{hennyjuliani.fhundip@gmail.com ${ }^{1}$, kadekwibawa@lecturer.undip.ac.id ${ }^{2}$ \} \\ Universitas Diponegoro, Indonesia ${ }^{1,2}$
}

\begin{abstract}
Development requires enormous funds. Investment is one of the ways that the Semarang City Government can absorb funds or invite investors to support development in the city of Semarang. The development of technology, information, the internet, and communication demand digital-based licensing services. The SI-IMUT application is a licensing-based service innovation developed by the Semarang City Government. The main problem at this time is related to the implementation of the SI-IMUT application. This paper aims to examine the urgency of an electronic good governance-based investment permit system policy in the city of Semarang and examine the implementation of the SI-IMUT application in providing accessible and integrated licensing services in the city of Semarang. This research uses doctrinal and non-doctrinal legal research, which is part of qualitative research with descriptive-analytical research specifications. The results showed that the implementation of electronic-based licensing services in the city of Semarang still pays attention to the principles of good governance to improve service quality. The SI-IMUT application is an innovation made by the Semarang City Government to realize easy, simple, and low-cost licensing services. The SI-IMUT application in its implementation is still hampered by many things, both technical and nontechnical. However, the launch of the application has become a symbol of the movement direction of Semarang City towards e-government and smart government.
\end{abstract}

Keywords: Licensing System, SI-IMUT, Good Governance

\section{Introduction}

Article 1 paragraph (3) of the 1945 Constitution of the Republic of Indonesia (UUD NRI 1945) clearly states that: "The State of Indonesia is a constitutional state" [1]. The concept of a rule of law that Indonesia owns is the concept of a rule of law that can improve the welfare of its people [2]. National development guaranteed by law is one way to achieve people's welfare or social welfare.

Wibawa [1] stated that: "national development is a series of efforts and actions undertaken to achieve national goals and ideals". In principle, national development focuses on developing development in the regions, both at the provincial and district/city levels. The success of regional development is a prerequisite for the success of national development. Regional strengthening through regional autonomy policies is the main door for local governments to be more innovative and work hard in implementing regional development.

The Semarang City Government also realizes that in this period of regional autonomy, the City of Semarang has carried out development activities in various fields of life to realize people's welfare. The successful development of the city of Semarang is very costly. The funds 
owned by the Semarang City Government are insufficient to carry out regional development in total.

Sources of regional development financing can be obtained from within the country and/or originating from abroad, including taxes, grants, domestic and/or foreign loans, investment, or proceeds from export activities. Investment is one of the leading sources of financing in the implementation of development. It is because investment involves other parties participating in the implementation of development.

Investment is seen as one way to improve people's welfare by increasing infrastructure development activities that absorb labor and improving infrastructures such as electricity that is still lacking in various regions and other facilities and infrastructure that can support development. Investment plays a vital role in driving the nation's economic life because the formation of capital increases production capacity, increases national income, and creates new jobs. In this case, it will further expand employment opportunities [3]. Investment can also be interpreted as spending or spending by investors or companies to buy capital goods and equipment to increase the ability to produce goods and services available in the economy [4].

Local governments throughout Indonesia are currently competing to attract investors to invest in their regions. The Semarang City Government, under the leadership of Hendrar Prihardi is actively attracting investors to invest in the city of Semarang. During the Covid-19 pandemic, Semarang City still recorded positive numbers in terms of investment. It is recorded that Semarang City investment in 2020 is IDR 21,8 trillion and can absorb around 65,000 workers.

Furthermore, there are five main problems attracting investors to invest in Indonesia. The first and foremost problems relate to uncertain regulations, complex licensing, and a lack of coordination between government agencies and central-regional coordination. Other issues include complex tax collection, slow tax collection services, and unattractive fiscal incentives for investors; problems related to land acquisition; a limited number of skilled workers and complicated procedures for obtaining foreign worker permits; and slow dwelling time at the port and lack of infrastructure due to limited funds for financing [4].

Particularly regarding uncertain regulations and licensing procedures considered complicated and high cost, the Semarang City Government has begun introducing an accessible and integrated investment permit system through the SI-IMUT application. The existence of this system is in line with the development of the digitalization era, which demands openness, accountability, simplicity, low cost. It is in line with the demands of the principles of good governance in managing governance based on electronic (e-government) and intelligent government.

Electronic-based licensing services are a public need in the era of digitalization. The policy to develop an electronic-based investment permit system in Semarang City is in line with the mandate of Law No. 25 of 2007 concerning Investment (Law on Investment) and Government Regulation No. 24 of 2018 concerning Electronically Integrated Business Licensing Services (Govreg No. 24 of 2018).

This paper examines the urgency of developing an electronic-based investment permit system in the context of realizing good governance in licensing services in Semarang and examining the implementation of policies for implementing the SI-IMUT application in the city of Semarang. This paper is different from several previous studies discussing licensing policies, the development of electronic-based licensing systems, and research related to licensing services and good governance.

Ansari [5] writes about the Omnibus Law to organize investment in Indonesia. Sutrisno and Poerana [6] write about legal reform and the realization of foreign investment during the era of 
President Joko Widodo. Suriadinata [7] examines the preparation of investment laws and their correlation with the preparation of the Omnibus Law. Fadhilah and Prabawati [8] write about the implementation of integrated electronic online single submission (OSS) licensing services for a study at the Nganjuk Regency Investment and One-Stop Integrated Services Service (DPMPTSP). Arliman [9] writes that investment in economic development in tourism is crucial, primarily to facilitate tourism development in West Sumatra. Widanta [10], the research focus aims to identify the condition of development in Bali Province from a macro aspect (finance system and investment), the problems of what still be faced, and what paid attention to to improve the quality of regional development.

Based on this brief description, there is a clear difference between the focus of the research study and the previous related research. This paper focuses on developing an accessible and integrated investment permit system (SI-IMUT application) specifically in Semarang.

\section{Research Methods}

Legal research can be divided into two, namely: doctrinal legal research and non-doctrinal legal research. This research uses doctrinal legal research supported by non-doctrinal legal research. This research uses a regulatory approach by using secondary data related to doctrinal legal research [11]. In the regulatory (statutory) approach, an analysis is carried out on the 1945 Constitution of the Republic of Indonesia, the Investment Law, Gov. Reg. No. 24 of 2018, and Semarang Mayor Regulation No. 70 of 2019. Regarding non-doctrinal legal research using a qualitative approach.

Data and materials were collected through the literature study method (secondary data), interviews, and observations (for primary data). Interviews were conducted on Semarang Local Government Officials ( 2 persons) and the community ( 5 persons) as subjects and objects of the application. The research location is in the Semarang City Investment Service and One-Stop Services (DPMPTSP). Analysis of the data and materials was carried out qualitatively. Withdrawal of conclusions is made inductively. Inductive reasoning is a way of thinking to conclude from observations of particular things into general or universal symptoms [12].

\section{Results and Discussion}

\subsection{The Urgency of Electronic Good Governance Based Investment License System Policy in Semarang City}

The development of technology, information, the internet, and communication is very fast, bringing significant changes to all aspects of human life. Slowly but surely, the world is changing from the analog era to the digital era. Technically, digitization is the process of changing all forms of information (numbers, words, images, sound, data, and motion) encoded into bits (binary digits) so that data manipulation and transformation (bit streaming) is possible, including multiplication, reduction, and addition [13].

In the current digital era, permits can be processed online from previously offline ones. This system change is expected to improve the quality of public services, especially investment licensing services, to be more optimal. Classic problems related to licensing services, such as 
slow or convoluted service, services that ask for many requirements, services that cost much money, services that do not have clarity regarding the time of the permit, and other problems; should not appear again in the digital era. Digitalization in the investment permit system, especially in Semarang, is expected to realize licensing services that are fast, easy, simple, open, and low cost.

Semarang City Government policy to realize investment licensing services electronically and digitally begins with the launch of the SI-IMUT application on May 2, 2018. The application can be accessed via the page: https://izin.semarangkota.go.id/siimut. The SI-IMUT application is a development of the SINAKES (Health Information System) application launched by the Semarang City DPMPTSP: a system that integrates three health agencies for licensing health workers.

The SI-IMUT application is an Online Single Submission (OSS) system created by the Semarang City Government to make it easier for business people to take care of their business licenses. Almost all business and investment licenses in various business sectors must be administered and issued through the OSS (SI-IMUT Application).

The operation of the application is an application of the principles of good governance in electronic form. The principles of good governance still underlie the implementation of licensing even though it has been carried out digitally. The implementation of public services in the licensing sector is based on the principles of good governance. Implementing public services is not solely based on the government or state. However, it must involve all private (private or corporate) components and the community itself [1]

The quality of public services that are not yet optimal, as expected by the community, will reduce the essence of the government's (state) goal of realizing social welfare for all Indonesian people [1]. Furthermore, Wibawa [1] stated that: for this reason, one of the efforts that must be done immediately in realizing good and prime public services is optimizing the openness of public information in the delivery of public services. Based on this, the SI-IMUT application is still based on the principles of good governance.

It is in line with Article 4 letter h of Law No. 25 of 2009 concerning Public Services (Public Law), which emphasizes that one of the principles in implementing public services is the principle of openness. Furthermore, in the elucidation of Article 4 letter $h$ of the Public Service Law, every service recipient can easily access and obtain information about the desired service.

Applying the principles of good governance in the delivery of public services, especially electronically (digitally) in the field of investment licensing, will keep away from the cultural practices of corruption and the illegal levy mafia. E-government is one-way developing countries can focus on developing good governance and strengthening civil society to improve the quality of government and motivate citizens to participate in the political process [14]. Egovernment is applying and utilizing information communication technologies (ICT) in the public sector for its effective delivery of operations and services while enhancing transparency and accountability of informational transactions within and among governments. The benefit of administering permits online: the public or business actors can take care of all kinds of things licensing in one place, cost and time efficiency. This condition will create a competitive and conducive investment environment. Apart from that, it also bridges the gap between citizens and their government and empowers and benefits citizens and businesses through access to and use of information [15][16][17]. 


\subsection{Implementation of the SI-IMUT Application to Realize Easy and Integrated Investment Licensing Services in the City of Semarang}

Mayor Hendrar Prihadi stated that four sectors are great opportunities for investment in Semarang City, namely:

a. Investment in light rail (LRT) construction, investment related to urban mass transportation connected to Ahmad Yani International Airport;

b. Underground development in the Simpang Lima area, where this project will connect between Pandanaran Road-Ahmad Yani Road and Pahlawan Road-Gajahmada Road;

c. Construction of the Semarang Expo Center and the waste power plant project in JatibarangSemarang [18]. Apart from these four projects, the Semarang City Government has also opened investment in various fields: tourism, education, health, and others.

The SI-IMUT application is present as an innovation of the Semarang City Government (DPMPTSP) because of these social phenomena. Based on Semarang Mayor Regulation No. 70 of 2019 concerning Delegation of Authorities for Signing Licensing and Non-Licensing to the Head of the Semarang City Investment and One-Stop Integrated Services Service, 174 types of licensing and non-licensing services can be accessed through the SI-IMUT application. Public service innovation in the investment licensing sector, in the form of the SI-IMUT application at DPMPTSP Semarang City, is one of the actualizations of applying the principles of good governance.

The SI-IMUT application as a new application in licensing management in Semarang City is still constrained by several problems, including:

a. There are still problems with the unstable internet network so that service users are still complicated to access the SI-IMUT application. The causes of the unstable network are inadequate internet capacity and internet network traffic. In addition, the government is slow in accelerating digital infrastructure;

b. The SI-IMUT service application is still not perfect. It can be seen from the features that must be completed;

c. Less than optimal understanding regarding the types of licensing services served through the SI-IMUT application;

d. Limited infrastructure and qualified human resources to undergo the SI-IMUT application. Government employees who handle the SI-IMUT application are over 45 years old. They are still lacking in mastery of technology.

Responding to this, Semarang City DPMPTSP, as the institution authorized to manage to license, has made several efforts to minimize problems that arise, including:

a. Submission of budgets related to increasing the server capacity of the SI-IMUT application as well as increasing network capacity at DPMPTSP, making it easier for employees and service users to access the SI-IMUT application;

b. Enhancing features in the SI-IMUT application by forming a special team related to the field of information technology;

c. Organizing workshops and training for employees in the Semarang City DPMPTSP environment related to information technology, especially SI-IMUT application services;

d. Addition of qualified personnel to handle licensing services electronically or digitally;

e. Procurement of goods complements public service infrastructure advice, such as laptops, computers, monitors, etc. Completeness of facilities and infrastructure, work equipment, and 
other support, including the provision of telecommunications and information technology facilities, is critical in realizing satisfactory service quality;

f. Conducting outreach for the public, especially users of licensing services, aims to more and more people understand the procedures and requirements for applying for investment permits or business permits electronically (through the SI-IMUT application).

\section{Conclusion}

Based on this description, the conclusions that can be drawn are: the development of digitalization requires changes to the management of investment licensing. Digital-based licensing services must be implemented to realize open, easy, simple, and inexpensive public services. The implementation of electronic-based services still has to pay attention to the principles of good governance. Applying the principles of good governance in public services will improve service quality.

The SI-IMUT application is an innovation of the Semarang City Government in providing public services in the licensing sector. Although the SI-IMUT application still has many shortcomings, this application is the beginning of the movement of electronic or digital-based services in the city of Semarang. Improving applications and being supported by other factors outside the application will gradually realize e-government and smart government in government management in the city of Semarang.

\section{Acknowledgments}

We are very grateful to the Faculty of Law, Universitas Diponegoro for their support, both material and non-material in nature, so that we can complete this research well and be able to present it at the $2^{\text {nd }}$ ICOLEG 2021.

\section{References}

[1] K. C. S. Wibawa, "Urgensi Keterbukaan Informasi dalam Pelayanan Publik sebagai Upaya Mewujudkan Tata Kelola Pemerintahan yang Baik," Adm. Law Gov. J, vol. 2, no. 2, pp. 218-234, 2019.

[2] Y. Yorisca, "Pembangunan Hukum Yang Berkelanjutan: Usaha Mencapai Pembangunan Nasional Yang Berkelanjutan,” J. Legis. Indones., vol. 17, no. 1, pp. 98-111, 2020.

[3] M. P. Todaro, Pembangunan Ekonomi di Dunia Ketiga, Ketujuh. Jakarta: Erlangga, 2000.

[4] R. Sulistiawati, "Pengaruh investasi terhadap pertumbuhan Ekonomi dan penyerapan tenaga kerja serta kesejahteraan masyarakat di Provinsi di Indonesia," J. Ekon. bisnis dan kewirausahaan, vol. 3, no. 1, pp. 29-50, 2012.

[5] M. I. Ansari, "Omnibus law untuk menata regulasi penanaman modal," J. Rechts Vinding Media Pembin. Huk. Nas., vol. 9, no. 1, p. 71, 2020.

[6] N. Sutrisno and S. A. Poerana, "Reformasi Hukum dan Realisasi Investasi Asing pada Era Presiden Joko Widodo," Undang J. Huk., vol. 3, no. 2, pp. 237-266, 2020.

[7] V. Suriadinata, "Penyusunan Undang-Undang di Bidang Investasi: Kajian Pembentukan Omnibus Law di Indonesia," Refleks. Huk. J. Ilmu Huk., vol. 4, no. 1, pp. 115-132, 2019.

[8] A. Nur Fadhilah and I. Prabawati, "Implementasi Pelayanan Perizinan Berusaha Terintegrasi 
Secara Elektronik Online Single Submission (OSS) Studi Pada Dinas Penanaman Modal dan Pelayanan Terpadu Satu Pintu (DPMPTSP) Kabupaten Nganjuk,” Publika, vol. 7, no. 4, 2019.

[9] L. Arliman, "Peran Investasi dalam Kebijakan Pembangunan Ekonomi Bidang Pariwisata di Provinsi Sumatera Barat," Kanun J. Ilmu Huk., vol. 20, no. 2, pp. 273-294, 2018.

[10] A. A. B. Widanta, "Peranan Pembiayaan Pembangunan dan Investasi dalam Pembangunan Daerah," INPUT J. Ekon. dan Sos., vol. 1, no. 2, p. 43811, 2008.

[11] K. C. S. Wibawa and A. Putrijanti, "The Reconstruction of Public Information Dispute Resolution as the Effort in Realizing Substantive Justice in Indonesia," J. Environ. Treat. Tech., vol. 9, no. 1, pp. 110-116, 2021.

[12] I. Mustofa, "Jendela Logika dalam Berfikir; Deduksi dan Induksi sebagai Dasar Penalaran Ilmiah," El-Banat J. Pemikir. Dan Pendidik. Islam, vol. 6, no. 2, pp. 1-21, 2016.

[13] A. Budiman, "Model Pengelolaan Digitalisasi Penyiaran di Indonesia," J. Polit. Din. Masal. Polit. Dalam Negeri dan Hub. Int., vol. 6, no. 2, 2016.

[14] R. Tassabehji, R. Hackney, and T. Maruyama, "Evaluating Digital Public Services: a contingency value approach within three "exemplar'sub-Sahara developing countries," 2019.

[15] L. Alzahrani, W. Al-Karaghouli, and V. Weerakkody, "Analysing the critical factors influencing trust in e-government adoption from citizens' perspective: A systematic review and a conceptual framework," Int. Bus. Rev., vol. 26, no. 1, pp. 164-175, 2017.

[16] O. Al-Hujran, M. M. Al-Debei, A. Chatfield, and M. Migdadi, "The imperative of influencing citizen attitude toward e-government adoption and use," Comput. Human Behav., vol. 53, pp. 189-203, 2015.

[17] K. J. Bwalya, "Factors affecting adoption of e-government in Zambia," Electron. J. Inf. Syst. Dev. Ctries., vol. 38, no. 1, pp. 1-13, 2009.

[18] A. Pujakesuma, "Wali Kota Hendi buka empat paket peluang investasi di Kota Semarang," Merdeka.com, 2018. https://semarang.merdeka.com/kabar-semarang/wali-kota-hendi-bukaempat-paket-peluang-investasi-di-kota-semarang-181017e.html. 